\title{
Editorial
}

\section{Perspektif Ginekologi Fistula Fesikovaginal}

\author{
Benny Hasan Purwara \\ Departemen Obstetri \& Ginekologi Fakultas Kedokteran Universitas Padjadjaran \\ Rumah Sakit Umum Pusat Dr. Hasan Sadikin Bandung \\ Korespondensi: Benny Hasan Purwara, Email: bennhp3042@gmail.com
}

Etiologi fistula vesiko vaginal (FVV) telah berubah dari akibat obstetri menjadi lebih terkait dengan tindakan histerektomi. Meskipun banyak publikasi tentang hal ini, namun pengelolaan FVV tetap menjadi sumber perdebatan. Pilihan pengelolaan masih menjadi masalah mendasar, seperti pendekatan bedah yang lebih disukai dan waktu operasi yang optimal masih sangat bervariasi.

Di negara-negara berkembang, penyebab utama FVV adalah obstruksi akibat partus lama $(97 \%),{ }^{1}$ sebaliknya di negara-negara industri cedera iatrogenik saluran kemih dan konsekuensi pembedahan ginekologis menjadi penyebab paling umum. Risiko penyulit FVV terjadi pada 0,8 per seratus histerektomi, sedangkan penyebab lain adalah keganasan dan iradiasi pelvis. ${ }^{2}$ Penyebab lain FVV adalah neoplasma ganas dan iradiasi pelvis. Berbeda dengan fistula obstetrik dan iradiasi, yang khas pada fistula pascaoperasi (pasca histerektomi) adalah hasil dari trauma yang muncul lebih cepat terlihat dan terlokalisasi pada jaringan sehat.

Meskipun FVV insidensi cukup tinggi, namun belum ditemukan algoritma standar untuk pengelolaannya. Pengelolaan konservatif termasuk drainase kandung kemih berkepanjangan, suntikan fibrin, fulgurasi dan lainnya,, merupakan pilihan yang masuk akal pada kasus dengan FVV kecil, bersih dan bukan kasus keganasan. Operasi merupakan pendekatan yang paling umum dengan tingkat keberhasilan bervariasi antara 75-95\% walaupun dengan berbagai variasi teknik. ${ }^{2}$ Berdasarkan kajian literatur, beberapa rute yang berbeda seperti teknik Latzko, open transabdominal, transvaginal, laparoskopi, robotik, endoskopi trans-urethral dengan atau tanpa interposisi jaringan telah dilaporkan, tetapi belum ditemukan laporan penelitian keberhasilan hasil prosedur bedah dibandingkan dengan prosedur konservatif. Belum ada ada konsensus umum mengenai kapan waktu yang tepat untuk perbaikan dengan keberhasilan paling baik. Pengelolaan dengan keberhasilan yang didokumentasikan dengan baik dan tingkat komplikasi serta waktu bedah yang optimal pada saat ini masih sulit ditemukan. Mayoritas laporan ilmiah terdiri dari laporan kasus dan seri kasus secara retrospektif. Sebagian kecil penelitian, menggunakan pilihan pengobatan konservatif pada perawatan fistula tunggal, karena mayoritas pasien diobati dengan pembedahan $(96,4 \%)$. Pendekatan bedah yang disukai adalah rute transvaginal, diikuti oleh transabdominal/transvesical approach, pendekatan laparoskopi/ robotik dan teknik operasi gabungan dengan tingkat keberhasilan yang dilaporkan masingmasing sebesar $93,82 \%, 97,05 \%, 98,87 \%$ dan $90,70 \% .{ }^{3}$ Keberhasilan pengelolaan konservatif hanya dengan drainase kateter berkepanjangan saja, sangat rendah, yaitu sekitar $8 \%$. Beberapa penulis melaporkan bahwa pengobatan konservatif hanya berhasil pada fistula kecil, dan mayoritas pasien akan membutuhkan perbaikan bedah definitif. ${ }^{2}$ Belum ada penelitian yang membandingkan tanpa bedah dengan strategi perawatan bedah. Meskipun operasi sejauh ini merupakan rekomendasi paling umum, namun bukti mengenai perawatan pasca bedah masih sulit ditemukan. Berbagai teknik dan pendekatan bedah yang berbeda telah dijelaskan dalam beberapa literatur, tetapi pilihannya terutama tergantung pada lokasi, keparahan dan ukuran fistula, selain itu hanya beberapa penelitian yang membandingkan berbagai prosedur bedah/pendekatan untuk FVV. Ou dkk.(2004), mengevaluasi tiga teknik bedah yang berbeda 
pada pasien dengan perbaikan fistula primer. Data mereka menunjukkan bahwa perbaikan laparoskopi cukup layak dan menghasilkan morbiditas yang lebih rendah daripada perbaikan konvensional transabdominal dan pervaginam. ${ }^{4}$ Perbaikan transvaginal FVV berulang tanpa interposisi jaringan sama berhasilnya seperti pada perbaikan primer. ${ }^{5}$ Rajamaheswari dkk. melaporkan hasil antara perbaikan pervaginam dan transabdominal, juga melaporkan tingkat keberhasilan yang sebanding antara kedua kelompok. ${ }^{6}$ Prinsip terpenting perbaikan upaya pertama adalah membuat penutupan kedap air yang bebas tegangan, dan rute pembedahan haruslah yang memberikan kemungkinan penutupan yang terbaik. Prinsip ini dapat dicapai melalui pendekatan pervaginam, transabdominal atau endoskopi. Meskipun pilihan teknik sebagian tergantung pada karakteristik fistula namun pengalaman bedah juga merupakan faktor penting untuk keberhasilan suatu tindakan pembedahan FVV. Meskipun teknik bedah yang berbeda telah dijelaskan, konsensus untuk pendekatan ideal untuk koreksi bedah FVV masih diperlukan. Secara umum, sebagian besar ahli bedah ginekologi lebih memilih pendekatan pervaginam, yang dikaitkan dengan tingkat morbiditas yang lebih rendah dan dengan hasil yang sama baiknya. ${ }^{7,8}$ Dua teknik perbaikan vagina yang paling sering dilaporkan termasuk teknik Latzko dan penutupan berlapis. Dari beberapa laporan ilmiah ditemukan bahwa, perbaikan fistula vagina dilakukan pada sebagian besar kasus dengan tingkat keberhasilan yang dilaporkan sebesar $93,82 \%$. Seratus tujuh pasien yang dikelola secara tehnik kolpokleisis parsial (perbaikan Latzko), ternyata $89 \%$ sembuh pada operasi primer. ${ }^{9}$

Meskipun tidak semua laporan penelitian menyertakan mengenai karakteristik fistula, namun diperkirakan pendekatan pervaginam untuk perbaikan fistula dilakukan pada mayoritas pasien dan oleh karena itu secara ilmiah dianggap merupakan prosedur bedah yang harus dilakukan oleh operator yang berpengalaman. Pendekatan transabdominal dapat dilakukan dengan menggunakan pendekatan transvesikal atau teknik extravesikal (teknik bivalve) terutama diindikasikan untuk fistula yang terlokalisasi atau kompleks. Tingkat keberhasilan yang dilaporkan sebesar 97,05\%. ${ }^{7}$ Mayoritas kasus-kasus ini dikelola dengan penambahan sistem graft, namun karena adanya inkonsistensi uji coba yang disertakan dan kurangnya data karakteristik fistula, maka para ahli tidak dapat membuat rekomendasi yang pasti. Pendekatan laparoskopi semakin sering dilakukan, Chibber dkk (2005), menjelaskan pendekatan teknik laparoskopi O'Conor yang memberikan penurunan morbiditas dan pemulihan lebih cepat. ${ }^{10}$

Tinjauan sistematis dengan 44 penelitian yang memenuhi syarat, membandingkan tingkat keberhasilan antara perbaikan transkripsi laparoskopi / robotik dan teknik perbaikan laparoskopik ekstravesika pada pasien FVV. Berdasarkan hasil-hasil tersebut, perbaikan FVV ekstravesika memiliki tingkat kesembuhan yang sama dibandingkan dengan pendekatan transvesik tradisional. ${ }^{10}$

Salah satu kontroversi utama dalam literatur adalah waktu yang ideal untuk intervensi bedah FVV pasca operasi. Para ahli berpendapat sampai saat ini masih adanya inkonsistensi tentang laporan hasil penelitian terkait waktu saat reparasi, sehingga belum terdapat kesepakatan dan rekomendasi yang dapat dilakukan mengenai waktu ideal untuk intervensi bedah. Angioli dkk. merekomendasikan menunggu 2-4 bulan sambil menggunakan drainase kandung kemih terus menerus. ${ }^{7}$ Beberapa penelitian lain menunjukkan perbaikan dini fistula kecil yang tidak terinfeks imempunyai tingkat keberhasilan yang lebih baik atau setidaknya sama dibanding penundaan pascaoperasi, sehingga penderitaan pasien berkurang dan lebih cepat memulai kehidupan normal. ${ }^{7,11,12}$ Beberapa laporan lain menunjukkan bahwa menunjukkan bahwa waktu perbaikan tidak mempengaruhi hasil. ${ }^{13}$

Komplikasi pasca operasi yang paling sering dilaporkan dalam literatur adalah de novo 
SUI, urgensi, nyeri / dispareunia, infeksi dan kegagalan. ${ }^{13}$

\section{Kesimpulan}

Terjadi pergeseran etiologi FVV, yaitu lebih sering disebabkan oleh trauma operasi pelvis. Karena lokasi fistula umumnya lebih jauh kearah puncak vagina, maka pendekatan trans abdominal baik konvensional atau laporoskopik, memberikan hasil yang lebih baik dari pada pendekatan secara trans vaginal. Masih belum ada standar prosedur baku yang disepakati untuk pengelolaan FVV.

\section{Daftar Pustaka}

1. Sharma S, Rizvi SJ, Bethur SS, Bansal J, Qadri SJF, Modi P. Laparoscopic repair of urogenital fistulae: a single centre experience. Journal of minimal access surgery. 2014;10(4):180.

2. Bazi T. Spontaneous closure of vesicovaginal fistulas after bladder drainage alone: review of the evidence. International Urogynecology Journal. 2007;18(3):329-33.

3. Bodner-Adler B, Hanzal E, Pablik E, Koelbl H, Bodner K. Management of vesicovaginal fistulas (FVVs) in women following benign gynaecologic surgery: A systematic review and meta-analysis. PloS one. 2017;12(2):e0171554.

4. Ou C-S, Huang U-C, Tsuang M, Rowbotham R. Laparoscopic repair of vesicovaginal fistula. Journal of Laparoendoscopic \& Advanced Surgical Techniques. 2004;14(1):17-21.

5. Pshak T, Nikolavsky $\mathrm{D}$, Terlecki R, Flynn BJ. Is tissue interposition always necessary in transvaginal repair of benign, recurrent vesicovaginal fistulae? Urology. 2013;82(3):707-12.

6. Rajamaheswari $\mathrm{N}$, Chhikara $\mathrm{AB}$, Seethalakshmi K, Bail A, Agarwal S. Trans-vaginal repair of gynecological supratrigonal vesicovaginal fistulae: A worthy option! Urology annals. 2012;4(3):154.

7. AngioliR,Penalver M, MuziiL, MendezL, Mirhashemi R, Bellati F, et al. Guidelines of how to manage vesicovaginal fistula. Critical reviews in oncology/hematology. 2003;48(3):295-304.

8. Ghoniem GM, Warda HA. The management of genitourinary fistula in the third millennium. Arab journal of urology. 2014;12(2):97-105.

9. Tancer M. Observations on prevention and management of vesicovaginal fistula after total hysterectomy. Surgery, gynecology \& obstetrics. 1992;175(6):501-6.

10. Chibber PJ, Shah HN, Jain P. Laparoscopic O'Conor's repair for vesico vaginal and vesico uterine fistulae. BJU international. 2005;96(1):183-6.

11. Blandy J, Badenoch D, Fowler C, Jenkins B, Thomas N. Early repair of iatrogenic injury to the ureter or bladder after gynecological surgery. The Journal of urology. 1991;146(3):761-5.

12. Badenoch D, Tiptaft R, Thakar D, Fowler C, Blandy J. Early repair of accidental injury to the ureter or bladder following gynaecological surgery. British journal of urology. 1987;59(6):516-8.

13. Melah G, El Nafaty A, Bukar M. Early versuslateclosureofvesicovaginal fistulas. International Journal of Gynecology \& Obstetrics. 2006;93(3):252-3. 